\title{
The Effect of Science, Technology, Engineering, and Mathematics (STEM) Learning on Students' Problem Solving Skill
}

\author{
Fathiah Alatas ${ }^{1}$, Nur Afriyati Yakin ${ }^{2}$ \\ UIN Syarif Hidayatullah Jakarta, Indonesia ${ }^{1,2}$ \\ fathiah.alatas@uinjkt.ac.id ${ }^{1}$,nunu.yakin15@mhs.uinjkt.ac.id ${ }^{2}$
}

Received: July $1^{\text {st }}, 2020$. Revised: September $3^{\text {rd }}, 2020$. Accepted: September $8^{\text {th }}, 2020$

Keywords :

STEM; Problem Solving Skill;

Work and Energy

\begin{abstract}
Problem solving is one of the abilities that must be mastered in the 21st century, lack of mastery of students' concepts in work and energy material has an impact on students' problem solving abilities. This research aims to measure students' problem solving skill on work and energy material. The research was used quasi-experiment with the design of a nonequivalent control group design. The subject of the research consist of 70 students at the 10th grade of one of high school in Kabupaten Tangerang with technique was used purposive sampling. The research used 10 essay questions as test instrument problem solving skill with 5 indicators of problem solving skill, namely visualize the problem, describe the problem in physics description, plan the solution, execute the plan and check and evaluate. The research result shows that is a effect of STEM learning on student's problem solving skill proven by student's problem solving skill of the experimental group increased higher $(N$ Gain 0.71 high category) compares to the control group (NGain 0,38 middle category).
\end{abstract}

\section{INTRODUCTION}

The 21st century exerts influence on various aspects of life, demands various skills that must be mastered by people in order to adjust to the times, including the development of science and technology. Partnership for 21st Century Skill was emphasized 21st century learning on some of the skills that must be possessed including critical thinking, problem solving, communication, collaboration, and creativity [1]. One of the skills that must be mastered in the 21st century is problem solving skill [2]. Teamwork, understanding of the main problems. and problem solving strategies are needed in problem solving skills [3]. But in fact, the ability to solve problems in learning physics is still low [4]. Students more often use mathematical equations in solving physics problems without analytical work, guess the formula used and memorize the questions that have been done to solve other problems [5]. According to research conducted by Ince, another obstacle is that students are not able to solve different problems even with the same concept [6]. Physics learning tends to emphasize concepts, but does not apply concepts that are understood in solving physical problems [7]. 
One of the concepts of physics that is closely related to daily life is work and energy. This concept teaches students to be able to think of finding problems and solve them with appropriate theories and concepts [8]. But in fact, students' mastery of work and energy concepts is relatively low [9]. In accordance with the results of a preliminary study in a sample school that students' understanding of work and energy material is still low, less than $50 \%$ of students can complete it. In line with that, research conducted by Rahmatina, that students' understanding of concepts in business materials and energy is still relatively low and students are still having difficulty working on business and energy questions [10]. Less than $50 \%$ of students can complete the material, most students still do not understand the basic concepts of work and energy material [11]. In fact, problem solving can be done if the concept of the lesson has been understood, applying the concept and using the relationship between the concepts with each other to different problems [12]. The low understanding of concepts, impact on the low ability of students' problem solving, therefore learning is needed that can construct knowledge and make learning more meaningful [13].

STEM learning can be used to lift everyday issues into learning that leads to more meaningful learning. According to Permanasari, STEM is a science learning alternative that can build a generation capable of facing the 21st century [14]. STEM learning is learning that is directly applied in the real world in the form of contextual problem solving based on problem solving [13]. STEM learning requires students to understand the core concepts of a material to be applied through the discovery of solutions and problem solving [15]. The STEM learning process is carried out with active learning methods that encompass communication, collaboration, problem solving, leadership, creativity, and others [16]. In the research conducted by Soros et al, stated that STEM learning methods can improve critical thinking skills and solve problems [17]. This research applies STEM in learning process to hone students' ability to solve problems in the concept of work and energy.

This research is intended to find out 1) the effect of STEM learning on problem solving skill, 2) improvement of problem solving skills from applying STEM learning and conventional learning, 3) student activities when applied STEM learning.

\section{METHOD}

The research was used a quasi experiment with the design of nonequivalent control group design. The subject of the research consist of 70 students in the 10th grade of one of high school in Kabupaten Tangerang with the technique was used purposive sampling. It was decided that X MIPA 2 as the experimental group using STEM learning and X MIPA 3 as the control group apllied conventional learning. Methods of data collection were tests and observation. The test method aims to obtain data on problem solving skill and the method of observation in this study aims to obtain data on student's attitudes during STEM learning. The indicator used is an indicator developed by Heller 1) to visualize the problem 2) describe the problem in physics description 3)plan the solution 4) execute the plan 5) check and evaluate [18].

This research has three phases procedure that includes: 1) The preparation phase consists of covering literatur, problem formulation research, sampling preparation of lesson plans, worksheets manufacture, test instrument and nontest. 2) The implementation phase begins by providing a pretest to find out the student's initial abilities and to determine the experimental group and the control group, treat the experimental group and the control group. When learning takes place, the observer makes observations related to the assessment of student activities. After the learning process is finished, each group is given a posttest to measure students' problem solving skill. 3) The analysis and reporting phase is carried out data processing and analysis, hypothesis testing up to drawing conclusions.

To analyze the increase in student problem solving ability, N-gain is used as a data analysis technique. The $\mathrm{N}$-gain calculation uses the following formula [19]: 
JIPF, Vol. 6 No. 1, January 2021

$$
N-\text { gain }=\frac{\text { posttest score }- \text { pretest score }}{\text { maximum score- }- \text { pretest score }}
$$

The criterion for increasing the problem-solving ability based on N-gain is the high category if $\mathrm{N}$-gain $>0,7$, medium category if $\mathrm{N}$-gain between $0,3-0,7$ and low category if $\mathrm{N}$-gain $<0,3$ [20]. Hypothesis testing was conducted to find differences in problem-solving abilities between the experimental group and the control group. Before testing the hypothesis, the normality and homogeneity tests were carried out. The non-test instrument data in this study are in the form of observations that aim to measure student activity during STEM learning. Data processing can be calculated using the following formula:

$$
\text { percentage }=\frac{F}{N} \times 100 \%
$$

Interpretation of student activity observation criteria if $81 \%-100 \%$ is very good, $61 \%-80 \%$ is good, $41 \%-60 \%$ is medium, $21 \%-40 \%$ is less and $0 \%-20 \%$ is very less.

\section{RESULTS AND DISCUSSIONS}

The results obtained in the form of pretest and posttest data, N-Gain from the experimental group and the control group, as well as the results of observations of student activities while learning. Posttest pretest result data are described in the form of scores. Before being treated, the sample was given a pretest with the aim of knowing the initial abilitie. After being treated, the sample is given a posttest to measure the final outcome of the problem solving abilities. The results of the pretest of the control group and the experimental group are described in the following Table 1.

Table 1. Measures of the Pretest Data Distribution of the Control and Experimental Group

\begin{tabular}{ccc}
\hline Data Distribution & Control Group & Experiment Group \\
\hline Average & 17.29 & 13.20 \\
The minimum score & 31 & 29 \\
The maximum score & 4 & 2 \\
Median & 16 & 12 \\
Modus & 14 & 12 \\
Standar deviation & 5.85 & 6.25 \\
\hline
\end{tabular}

Based on Table 1, the average pretest score in the control group was 17.29 while in the experimental group was 13.20. This shows that the average score of the control group pretest is higher than the experimental group, it also forms the basis of the group with a low pretest score used as an experimental group when learning STEM learning will be applied (Science, Technology, Engineering and Mathematics). After being given treatment, both groups were given a posttest while the results are described in the following Table 2 .

Table 2. Measuring the Posttest Data Distribution of the Control and Experimental Group

\begin{tabular}{ccc}
\hline Data Distribution & Control Group & Experiment Group \\
\hline Mean & 49.49 & 74.51 \\
The maximum score & 84 & 88 \\
The minimum score & 12 & 51 \\
Median & 54 & 78 \\
Modus & 54 & 78 \\
Standard deviation & 19.35 & 8.36 \\
\hline
\end{tabular}

Based on Table 2 the results of the posttest that showed the students' final problem solving skills in the control group were 49,49 and in the experimental group were 74.51. It appears that the final problem solving ability of students in the experimental group is higher than in the control group. 
The normality test is done by processing the pretest and posttest score data from the control group and the experimental group. The normality test in this study used the Shapiro-Wilk test with the help of IBM SPSS Statistics software. The results of the pretest and posttest normality tests of the two samples can be seen in the following Table 3.

Table 3. Result of Normality Test

\begin{tabular}{ccc}
\hline \multicolumn{2}{c}{ Shapiro-Wilk Test } & Sig. \\
\hline \multirow{2}{*}{ Control group } & Pretest & 0.228 \\
& Posttest & 0.274 \\
\hline \multirow{2}{*}{ Experimental group } & Pretest & 0.188 \\
& Posttest & 0.001 \\
\hline
\end{tabular}

Table 3 shows that the value of sig. the pretest data of the two groups was more than 0.05 namely 0.188 for the control group, and 0.228 for the experimental group, so that the results of the pretest results of the control group and the experimental group were both normally distributed. Posttest data from the control group has a sig value. more than 0.05 which is 0.274 and the experimental group the value of sig. less than 0.05 which is 0.001 . So the decision of the posttest results of the control group is normally distributed while the experimental group is not normally distributed.

The homogeneity test was performed on the pretest and posttest data of the control group and the experimental group. The homogeneity test in this study used the Levene test with the help of SPSS software. Homogeneity test results of the pretest and posttest data in the control group and the experimental group are presented in the following Table 4.

Table 4. Result of Homogeneity Test

\begin{tabular}{ccc}
\hline & Pretest & Posttest \\
\hline Sig. & 0.879 & 0.000 \\
Levene's Test & Sig. $\geq 0,05=\mathrm{H}_{0}$ accepted \\
Result & homogeneous & not homogeneous \\
\hline
\end{tabular}

Table 4 shows that the value of sig. pretest data more than 0.05 is 0.897 while posttest data less than 0.05 is 0.000 . So that the decision of pretest data can be taken to have the same or homogeneous variants while the posttest data has a variance that is not the same or not homogeneous.

Based on the prerequisite test the statistical analysis shows that the control group pretest data and the experimental group are normally distributed, the second variant of the pretest group is homogeneous. Posttest data of the control group are normally distributed while the experimental group is not normally distributed with the second variant of the group that is not homogeneous. Hypothesis testing used in this research was parametric and non-parametric statistical tests, using SPSS software through t-test for pretest data and U-test for posttest data. The results of the pretest and posttest hypothesis tests can be seen in the following Table 5.

Table 5. Hypothesis Test Result

\begin{tabular}{ccc}
\hline & $\begin{array}{c}\text { Pretest } \\
\text { (t-test) }\end{array}$ & $\begin{array}{c}\text { Posttest } \\
\text { (Mann-Whitney U test) }\end{array}$ \\
\hline $\begin{array}{c}\text { Sig. (2-tailed) } \\
\propto\end{array}$ & 0.094 & 0.000 \\
Result & Sig. $\geq 0.05=\mathrm{H}_{0}$ accepted \\
$\mathrm{H}_{0}$ accepted & $\mathrm{H}_{1}$ accepted \\
\hline
\end{tabular}

Based on Table 5 the results of the posttest hypothesis test show that the alternative hypothesis $\left(\mathrm{H}_{1}\right)$ is accepted. Alternative hypothesis criteria that the average problem solving ability of the experimental group is higher than the control group, it indicates that STEM learning influences students' problem solving skill in work and energy material. In line with research conducted by Soros et al, the research 
stated that STEM learning methods can improve critical thinking skills and solve problems in physics lessons [17].

The results of the research in the experimental group after being given treatment in the form of intergated STEM learning and conventional learning in the control group showed that the problem solving abilities of students in the experimental group were superior to those of the control group. This is indicated by the increase in the problem-solving abilities of the two groups. Improved students' problem solving skills in the control group and the experimental group can be calculated with the N-Gain formula. The average $\mathrm{N}$-Gain results in each group can be seen in the following Table 6.

Table 6. N-Gain Result

\begin{tabular}{ccc}
\hline Group & N-gain & Category \\
\hline Control & 0.38 & Medium \\
Experiment & 0.71 & High \\
\hline
\end{tabular}

Table 6 shows the average N-Gain score for the control class of 0.38 can be interpreted to increase the problem solving skill of students in the control group in the medium category, and the experimental group the average $\mathrm{N}$-Gain score obtained by 0.71 with words another increase in students' problem solving skills in the experimental group was in the high category. It can be seen that there is a difference in the average score of N-Gain for the control group and the experimental group, an increase in students' problem solving abilities in the experimental group treated with learning STEM is higher than the increase in problem solving abilities in the control group who were not treated with STEM learning.

Improvement of each aspect of problem solving ability is obtained from the average N-gain in each group. The N-gain results for each aspect of students' problem solving abilities can be seen in the following Table 7.

Table 7. Results Average N-Gain Aspect of Problem Solving

\begin{tabular}{ccccc}
\hline \multirow{2}{*}{ Aspect } & \multicolumn{2}{c}{ Control group } & \multicolumn{2}{c}{ Experimental group } \\
\cline { 2 - 5 } & N-Gain & Category & N-Gain & Category \\
\hline Visualize the problem & 0.39 & Medium & 0.83 & High \\
Describe the problem & 0.54 & Medium & 0.80 & High \\
Plan the solution & 0.37 & Medium & 0.64 & Medium \\
Execute the plan & 0.31 & Medium & 0.58 & Medium \\
Check and evaluate & 0.29 & Low & 0.72 & High \\
\hline
\end{tabular}

Based on Table 7, the problem solving skill of the two groups increased in every aspect. Improved aspects of understanding the problem of the control group by 0.39 (medium category) and the experimental group by 0.83 (high category). The superiority of the experimental group in this aspect is due to the STEM learning there is a scientific inquiry phase that allows students to construct their own knowledge and in technology literacy students are directed to understand the problems contained in the discourse. The aspect of describing the problem into the physics concept of the experimental group was also superior with an increase of 0.80 (high category) compared to the control group which increased by 0.54 (medium category). That is because in the aspects of science inquiry and technology literacy in STEM learning students are trained to focus on problems, the teacher only acts as a facilitator who guides students to visualize problems based on known problems [20].

The aspect of planning a solution with the achievement of improvement in the experimental group is 0.64 (medium category) while the control group is 0.37 (medium category), the problem-solving ability of this aspect is improved due to the engineering design students are trained by designing simple experiments that are relevant and relevant to solve problems according to the concepts they find. In the aspect of engineering design communication and collaboration are also built in planning solutions, 
supported by research conducted by Stehle \& Peters-Burton that communication and collaboration are needed in constructing knowledge and problem solving [21]. Supported by other studies that aspects of engineering design in STEM learning can develop skills with a focus on constructing knowledge to solve problems [22].

Improvement in the aspect of implementing the solution, the experimental group was also superior compared to the control group with achievements of 0.58 (medium category) for the experimental group and 0.31 (medium category) for the control group and $\mathrm{N}$-gain in the aspect of evaluating solutions for the experimental group by 0.72 (high category) while the control group 0.29 (low category). Increased aspects of implementing solutions due to the training of mathematical abilities in the aspects of mathematical thinking, as previous research states that students are more motivated in assessing the mathematical context after applying STEM learning [23].

The high increase in problem solving skills in the experimental group due to the training of problem solving skills by applying STEM learning. During learning, students are given LKS (Student Worksheets) that are designed according to the STEM aspects to practice problem solving skills. Winarni et al stated that aspects of STEM learning are in line with the stages of students' problem solving abilities, because STEM learning are learning that is directly applied in the form of contextual problem solving based on problem solving [13]. STEM learning has four aspects including science inquiry, technology literacy, engineering design, and mathematical thinking [23]. In the science inquiry aspect, students to construct their own knowledge related to the concepts being studied [24]. When learning takes place students construct their initial knowledge by demonstrating and observing videos. The technology literacy aspect supports students to be technology literate and to be trained in their technology skills, students are familiar with and analyze the application of technology from the concepts being studied [24]. When student learning is presented with an overview related to the application of the technology being studied, then students are required to know and analyze the technology. students also use technology in search of finding solutions and relevant material from problem discourse after students have passed the stage of understanding the problem. The aspect of technology literacy in STEM worksheets as shown in Figure 1.

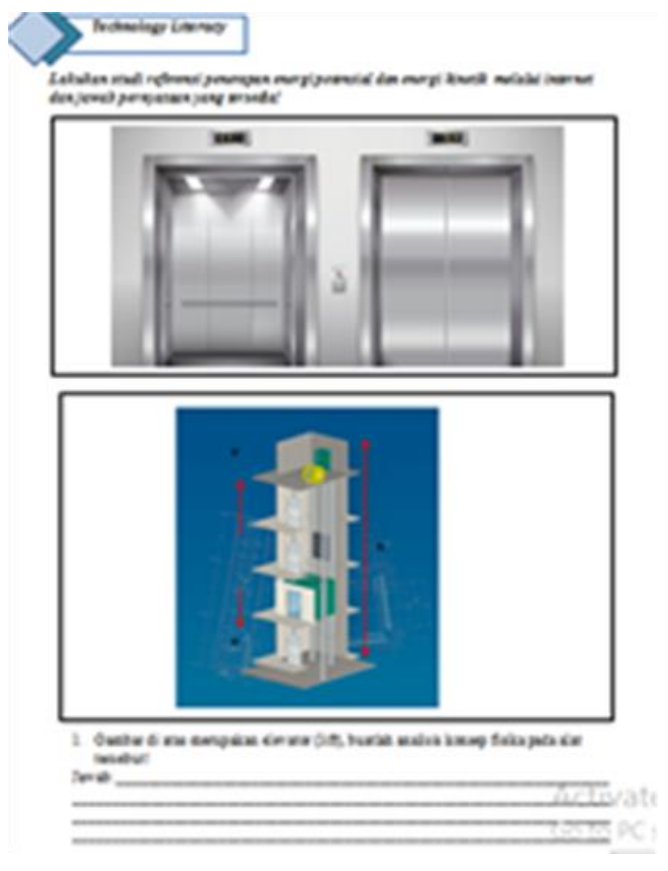

Fig 1. Aspect of Technology Literacy On Worksheet

In the aspect of engineering design, students plan solutions to solve problems by designing a simple experiment [23]. Students are faced with the stage of planning a solution then students use the 
knowledge they already have to create designs and experimental procedures that are suitable for solving problems. Student activities on the aspects of engineering design can be seen in Figure 2.

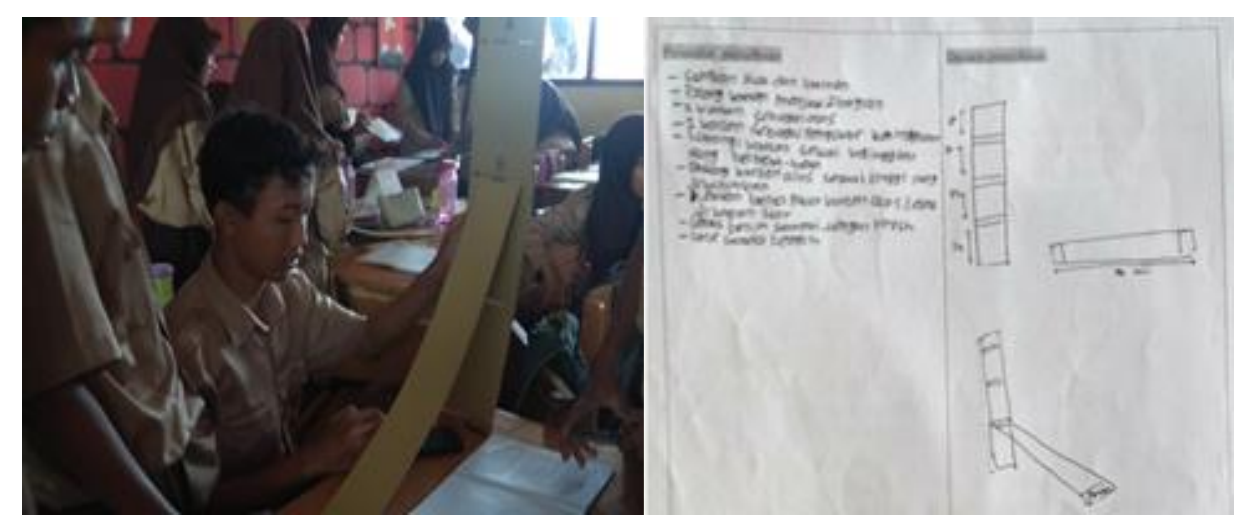

Fig 2. Student Answers To Engineering Design

Mathematical thinking aspects, students use mathematical abilities to carry out solutions by performing mathematical calculations based on data acquisition from experiments that have been designed and then students evaluate the problem solving solutions they have made [23]. The STEM aspect trains students in solving problems, as seen in the difference between the answers of the control group students and the experimental group presented in Figure 3.

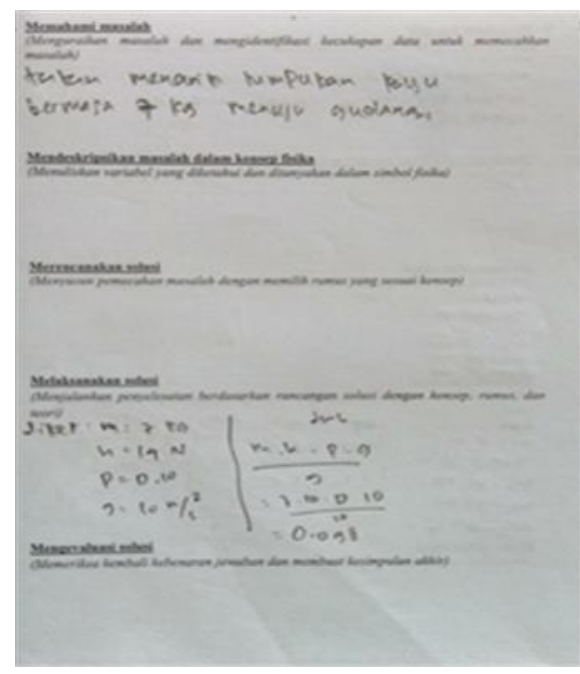

(a)

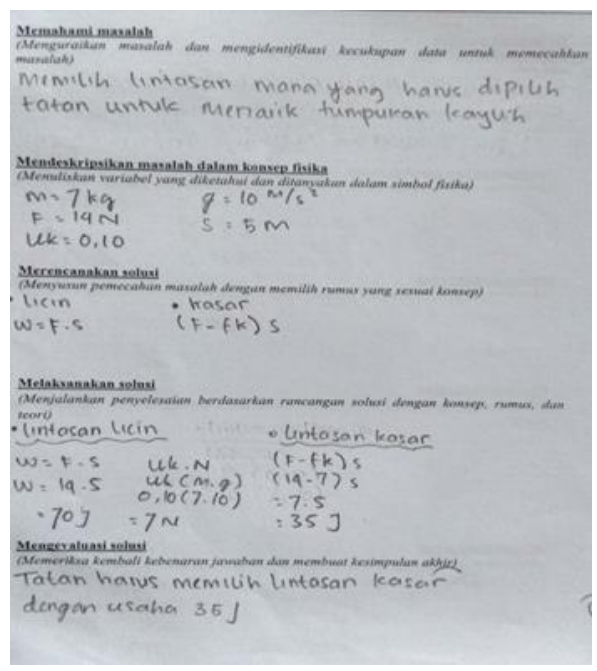

(b)

Fig 3. Problem Solving: (a) Control Group, (b) Experimental Group

Based on Figure 3, it can be seen that the control group cannot answer all aspects of problem solving ability completely, in contrast to the experimental group that can answer all aspects of problem solving ability. This shows that STEM trains problem solving abilities, because aspects of STEM learning are in accordance with aspects of problem solving abilities [13]. Netwong in her research stated that STEM learning can improve problem-solving abilities and student achievement [22]. Apriani et al in their research stated the problem-solving ability had increased after students were treated in the form of STEM-based learning [20].

The high increase in the experimental group was caused by students' interest and enthusiasm when learning STEM, this was supported by the results of observations made in the experimental group at three meetings found that $77.8 \%$ of students sought relevant facts in the aspects of science inquiry and technology literacy, in engineering design aspects $70.8 \%$ of students do the planning of solutions by making designs and experimental procedures, $83.3 \%$ of students actively participated in experimental 
The Effect of Science, Technology, Engineering, and Mathematics (STEM) Learning... Fathiah Alatas, Nur Afriyati Yakin

activities, $90.3 \%$ of students collaborated in experimental activities and in the aspects of mathematical thinking $83.3 \%$ of students had discussions regarding the results of experiments and evaluation of solutions. In line with previous research, that STEM learning is learning with active learning encompassing communication, collaboration, problem solving, leadership, creativity [25].

\section{CONCLUSION AND SUGGESTION}

Based on the results of this research concluded that (a) there is an effect of learning STEM on the ability of problem solving students on work and energy material (b) improvement of students' problem solving skills in the experimental group with an $\mathrm{N}$-Gain of 0.71 (high category), while the control group obtained an N-Gain of 0.38 (medium category) (c) the results of observations of student activities in the experimental group while learning STEM obtained an average percentage of $81.09 \%$ with a very good category.

Some suggestions that the authors propose after doing this research include (a) STEM learning should be carried out for subject matter that is not a theoretical concept (b) Implementation of STEM learning requires a long time, researchers and teachers should be able to allocate time should be possible so that learning can run effectively.

\section{REFERENCES}

[1] Framework for 21st Century Learning. (2011). Partnership for 21st Century Skill, pp. 1-2.

[2] Christiyoda, S., Widoretno, S., \& Karyanto, P. (2016). Pengembangan modul berbasis kemampuan pemecahan masalah pada materi sistem ekskresi untuk meningkatkan berpikir kritis. Inkuiri: Jurnal Pendidikan IPA, 5(1): 74-84.

[3] Zubaidah, S. (2016, December). Keterampilan abad ke-21: Keterampilan yang diajarkan melalui pembelajaran. In Seminar Nasional Pendidikan dengan Tema "isu-isu strategis pembelajaran MIPA Abad (Vol. 21, No. 10).

[4] Purnamasari, I., Yuliati, L., \& Diantoro, M. (2018, February). Analisis Kemampuan Pemecahan Masalah Fisika pada Materi Fluida Statis. In Seminar Nasional Pendidikan IPA 2017 (Vol. 2).

[5] Rahmat, M., \& Zulaikah, S. (2014). Kemampuan Pemecahan Masalah Melalui Strategi Pembelajaran Thinking Aloud Pair Problem Solving Siswa Kelas X SMA. Jurnal Fisika Indonesia, 18(54): 108-112.

[6] Ince, E. (2018). An Overview of Problem Solving Studies in Physics Education. Journal of Education and Learning, 7(4): 191-200.

[7] Azizah, R., Yuliati, L., \& Latifah, E. (2015). Kesulitan pemecahan masalah fisika pada siswa SMA. Jurnal penelitian fisika dan aplikasinya (JPFA), 5(2): 44-50.

[8] Indriyani, F., Siswanto, J., \& Khoiri, N. (2018). Pengaruh Modeling Instruction Terhadap Kemampuan Pemecahan Masalah Fisika Pada Materi Usaha Dan Energi Siswa Kelas X MIPA SMA Muhammadiyah Mayong Jepara. Jurnal Penelitian Pembelajaran Fisika, 9(1): 40-44.

[9] Sukma, B., Koes, S., \& Kusairi, S. (2016). Identifikasi Penguasaan Konsep Siswa pada Materi Usaha dan Energi. In Prosiding Semnas Pendidikan IPA Pascasarjana UM (Vol. 1).

[10] Rahmatina, D. I., Sutopo, S., \& Wartono, W. (2018). Identifikasi kesulitan siswa SMA pada materi usaha-energi. Momentum: Physics Education Journal: 8-14.

[11] Mustofa, Z., Sutopo, S., \& Mufti, N. (2016). Pemahaman Konsep Siswa SMA Tentang Usaha dan Energi Mekanik. In Prosiding Semnas Pendidikan IPA Pascasarjana UM (Vol. 1). 
[12] Yulianawati, D., Novia, H., \& Suyana, I. (2016). Penerapan Pendekatan Metakognitif Dalam Upaya Meningkatkan Kemampuan Pemecahan Masalah Fisika Siswa SMA Pada Materi Gerak Harmonik Sederhana. In Prosiding Semnas Pendidikan IPA Pascasarjana UM (Vol. 1).

[13] Winarni, J., Zubaedah, S., \& Supriyono, S. (2016). STEM: Apa, Mengapa, dan Bagaimana. In Prosiding Semnas Pendidikan IPA Pascasarjana UM (Vol. 1).

[14] Permanasari, A. (2016). STEM Education: Inovasi dalam Pembelajaran Sains. In Prosiding Semnas Pendidikan IPA Pascasarjana UM (Vol. 1).

[15] English, L. D. (2016). STEM education K-12: Perspectives on integration. International Journal of STEM education, 3(1): 3.

[16] Dewi, M., Kaniawati, I., \& Suwarma, I. R. (2018, May). Penerapan pembelajaran fisika menggunakan pendekatan STEM untuk meningkatkan kemampuan memecahkan masalah siswa pada materi listrik dinamis. In Quantum: Seminar Nasional Fisika, dan Pendidikan Fisika (pp. 381-385).

[17] Soros, P., Ponkham, K., \& Ekkapim, S. (2018, January). The results of STEM education methods for enhancing critical thinking and problem solving skill in physics the 10th grade level. In AIP Conference Proceedings (Vol. 1923, No. 1, p. 030045). AIP Publishing LLC.

[18] Heller, K., \& Heller, P. (2010). Cooperative problem solving in physics a user's manual. In Tersedia: http://www. aapt. org/Conferences/newfaculty/upload/Coop-Problem-Solving-Guide. $p d f$.

[19] Hake, R. R. (1998). Interactive-engagement versus traditional methods: A six-thousand-student survey of mechanics test data for introductory physics courses. American journal of Physics, 66(1): 64-74.

[20] Apriyani, R., Ramalis, T. R., \& Suwarma, I. R. (2019). Analyzing Students' Problem Solving Abilities of Direct Current Electricity in STEM-Based Learning. Journal of Science Learning, 2(3): 85-91.

[21] Stehle, S. M., \& Peters-Burton, E. E. (2019). Developing student 21 st Century skills in selected exemplary inclusive STEM high schools. International Journal of STEM Education, 6(1): 39.

[22] Netwong, T. (2018). Development of Problem Solving Skills by Integration Learning Following STEM Education for Higher Education. International Journal of Information and Education Technology, 8(9).

[23] Kelley, T. R., \& Knowles, J. G. (2016). A conceptual framework for integrated STEM education. International Journal of STEM Education, 3(1): 11.

[24] Vasquez, J. A., Sneider, C. I., \& Comer, M. W. (2013). STEM lesson essentials, grades 3-8: Integrating science, technology, engineering, and mathematics (pp. 58-76). Portsmouth, $\mathrm{NH}$ : Heinemann.

[25] Kaniawati, D. S., Kaniawati, I., \& Suwarma, I. R. (2015). Study Literasi Pengaruh Pengintegrasian Pendekatan STEM dalam Learning Cycle 5E terhadap Kemampuan Pemecahan Masalah Siswa pada Pembelajaran Fisika. In Prosiding Seminar Nasional Fisika (SiNaFi). 